\title{
Implementation of Image Enhancement Algorithm for Image Forensics Using Matlab
}

\author{
Fauzan Novaldi Suteja ${ }^{1}$, Eka Wahyu Hidayat ${ }^{2}$, Nur Widiyasono ${ }^{3}$ \\ ${ }^{1,2,3}$ Informatics Department, Universitas Siliwangi, Tasikmalaya, Indonesia \\ 11147006101@ studentunsil.ac.id, ${ }^{2}$ ekawahyu@unsil.ac.id, ${ }^{3}$ nur.widiyasono@unsil.ac.id
}

\begin{abstract}
The purpose of this journal is to explain the implementation of the image enhancement algorithm for image forensics. Image Forensic deals with the types of digital evidence in the form of digital image files. One of the most commonly used digital devices in providing digital evidence for forensic analysis is CCTV (Closed-Circuit Television). CCTV images have a low quality such as noise, blur, lack of light intensity, etc., so that the image must be enhanced so that forensic analysis can be done. To enhance image quality, an application is needed by applying the image enhancement algorithm. The algorithm applied to the application is a Low Pass Filter to increase low pixel intensity, High Pass Filter to increase high pixel intensity, Median Filter to replaces the original pixel value with the pixel center value of the image, Mean Filter to replaces the original pixel value with a value the average pixel of the image, the Gaussian Filter for reducing noise in the image, the Wiener Filter to reduce blur in the image, the Histogram Equalization spreads the image histogram value, Contrast Stretching to stretch the contrast intensity in the image and Bicubic Interpolation to increase the image size and resize the image. In this study, the application was built using MATLAB and the testing process for each algorithm was based on Timing-Run, MSE and PSNR parameters. From the test, the average MSE value is 1058.512083 and the PSNR value is $541.61875 \mathrm{~dB}$, which means that the resulting image has a fairly high level of similarity and the average time needed to process the algorithm for the image is 0.114627915 seconds.
\end{abstract}

Keywords- Image Enhancement Algorithms, Image Forensics, MSE, PSNR, Timing-Run

\section{INTRODUCTION}

Closed-circuit television (CCTV) is a device that serves to record surveillance and security purposes. CCTV is used to prevent crime and malfunction and is also used for other purposes such as monitoring industrial processes and traffic movements. CCTV is one of the most common digital devices in providing digital evidence for the purpose of forensic analysis [1][2]. CCTV has often been found in office buildings, banks, shopping centers and even used by small to medium scale stores and in the homes of uppermiddle-class people. The use of surveillance cameras has mostly been used as evidence of a crime or as a reference for law enforcers to recognize the perpetrators so that they can explore further information to arrest the perpetrators [3].

The problem from CCTV for forensic analysis is the quality of recording from CCTV that is often bad due to several factors such as the type of camera, configuration, and camera position [2] lighting on the CCTV installation which results in too bright or too dark, noisy images when sending through a transmission line, the image is less sharp, blurred, etc. [4] can affect the results of analysis of identification and processing of information related to events recorded on CCTV.

Enhancing image quality needs to be done so that CCTV results can provide complete information and identification accurately so that further analysis can be carried out. Some algorithms on image enhancement processing in this program are expected to be able to enhance the quality of each input image from CCTV according to image conditions and situations related to the right algorithm so that every possibility of CCTV image results can be solved with this program.
CCTV is basically categorized into video forensics because it deals with evidence in the form of video recordings [5]. The pre-processing process needs to be done to get the CCTV image that comes from the CCTV video recording frame. Algorithm Image Enhancement applied to the application is Convolution (which consists of Low Pass Filters, High Pass Filters, Median Filters, Mean Filters and Gaussian Filters) [6], [7], [8], [1], [9]

Histogram Equalization [10], [11], [12][12], [13], Wiener Filter

[14], Stretching Contrast [15], [10], [16], [17], [18] and Linear Interpolation [19], [20] All algorithms are collected in a program to process image quality enhancements. This image quality enhancement application is created using MATLAB. This application was made aimed at enhancing the quality of CCTV images that are both visually so that they can obtain complete information and accurate identification. This application is expected to help related parties in carrying out the process of improving image quality.

Related research to enhance image quality has been done before. some of them try to repair digital video [21], improve the screenshot results [20] and mammogram [22]. This study only compares the performance of Image Enhancement algorithms with other algorithms such as Histogram Equalization [10], [11], [12], Stretching Contrast [15], [10], [18], Convolution [6],[7], [12], , Wiener Filter [14] and Interpolation [19][20].

Research related to image quality enhancement has been done before. Some of them tried to repair digital video [21], improve the screenshots of images [20] and mammogram [22]. Some of them only compare the 
performance of the Image Enhancement algorithms with other algorithms such as Histogram Equalization [10], [11], [12], Stretching Contrast [15], [10], [16], [18], Convolution [6], [7], [12], [1], Wiener Filter [14] and Interpolation [19][20].

Related research to enhance image quality for forensic purposes that are relevant to this research is research on enhancing the quality of images of CCTV results [23]. The difference with the research conducted is the algorithm used. In the study [23] the algorithm used was only histogram equalization while in this study compiled algorithms to improve image quality. The limitation of this study is the image data sourced from CCTV with low quality visually taken from the results of CCTV screen capture by taking certain frames. While the purpose of this study is to create a program to improve image quality, apply the image enhancement algorithm to the program and test the algorithm used with the parameters MSE, PSNR and Timing-Run. [24]

\section{METHOD}

The method used in this study is an experimental method. This method applies direct trial activities to test images by trial and error. The stages carried out in this study can be seen in Figure 1 below:

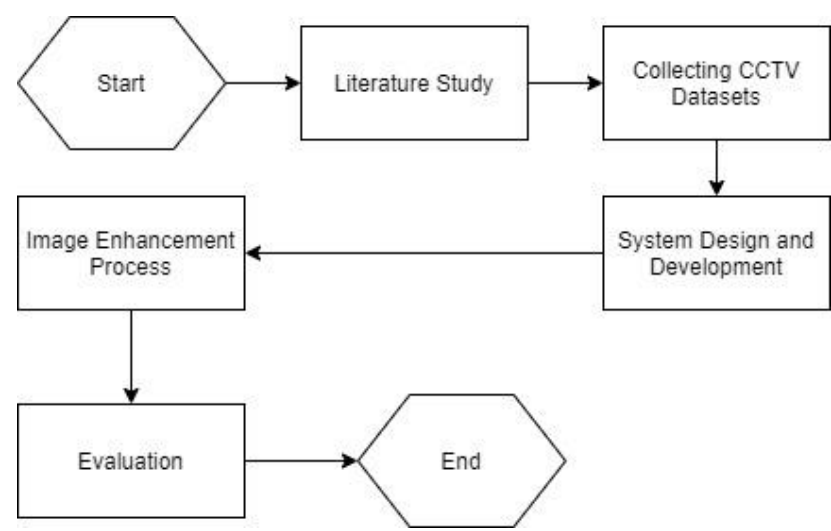

Figure 1. Research Method

\section{A. Literature Study}

A literature study is a process of studying and collecting data from the literature as well as relevant sources and supports this research. The theories related to research are obtained from journals, articles from the internet and books.

\section{B. Collecting CCTV Datasets}

Collecting CCTV datasets in this study is the process of taking CCTV data from various sources such as social media, where there are CCTVs and search results through the Google search engine. CCTV datasets taken are some CCTV videos with poor quality visually.

\section{System Design and Development}

System design and development is a stage in building image quality improvement programs. The software process model used in building image quality enhancement programs is an object-oriented approach, namely the UML method. The life cycle of object-oriented software development contains 3 macro processes: object-oriented analysis, object-oriented design, and object-oriented implementation.

\section{Image Enhancement Process}

The image enhancement process is the stage used to carry out the process of improving image quality. This process consists of 3 stages, the first stage is the preprocessing stage where at this stage CCTV dataset are screen capture, object detection and cut when needed. The second stage is the processing stage where the result of the preprocessing image will increase the image quality using an algorithm that has been applied to the program created. The third stage is the post-processing stage which is the testing phase using the MSE, PSNR and Timing-Run parameters

\section{E. Evaluation}

The evaluation at this stage will explain the results of the trial algorithm applied to the application of the CCTV image and explain the advantages and disadvantages that exist in this study, besides this stage will provide input on the shortcomings of the algorithms applied in the application, so that it can continued research related to the image enhancement algorithm for the process of improving CCTV image quality.

\section{RESULT AND DISCUSSION}

A. Results of Collecting CCTV Datasets

Collecting CCTV datasets in this study was obtained through Youtube video sharing sites with the quality or resolution of CCTV video recordings around 420TVL 700TVL. TVL stands for Television Line which means the density that can be obtained for an Analog CCTV to display video images on CCD sensors. TVL is obtained from the vertical lines contained in the screen. So the bigger the TVL, the smaller the line density, so that it can produce a denser image when enlarged the resolution of the TV screen or monitor. The CCTV dataset is screen capture by taking frames in CCTV footage videos using Adobe Premiere Pro tools.

Screen capturing or taking CCTV video recording frames produces an image with dimensions around 1280x720px with a resolution depth of around 96x96dpi. The image format or image extension used is .jpg.[18], [25][26][27]

B. Results of Application Development

The results of this application development include the results of implementation and the results of preprocessing application testing.

Implementation of the interface is the result of the display that will be used in the application to enhance 
image quality. This application will display 3 pages consisting of the main page, algorithm page and measurement page. The pages in this application are as follows:

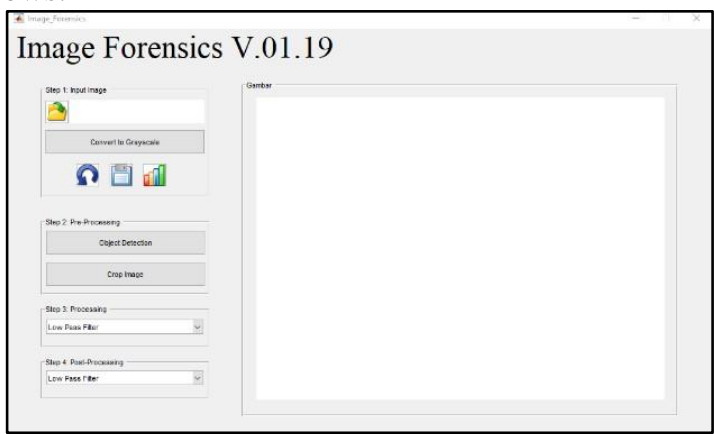

Figure 2. Display of the Application Main Page

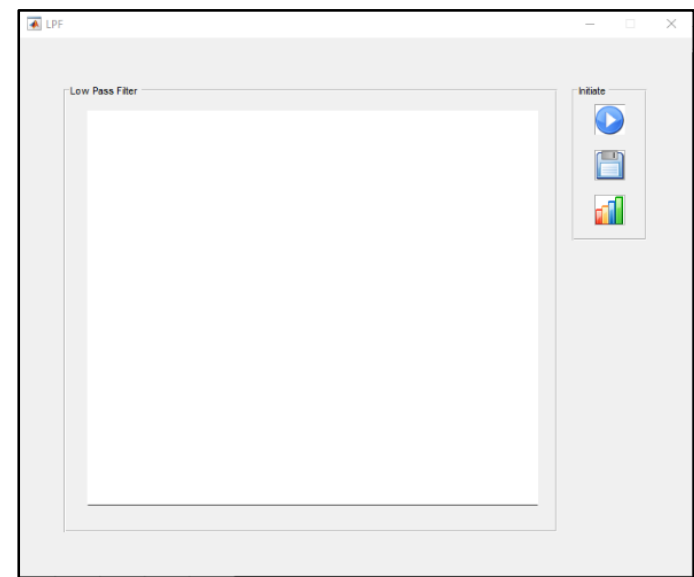

Figure 3. Page Views Algorithm

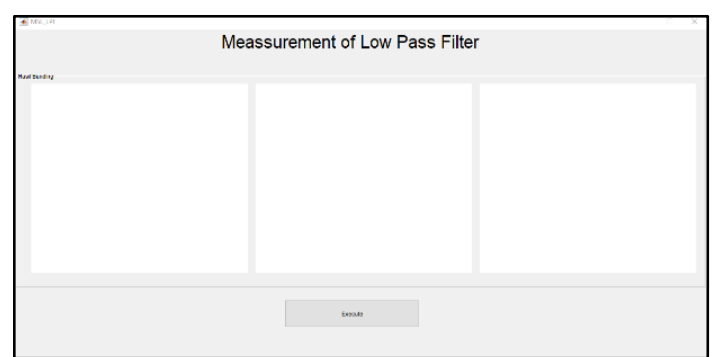

Figure 4. Display of Measurement Pages.Application Testing

From the results of the development of applications that have been built, the application has been able to carry out an initiate image process which consists of the process of converting RGB to Grayscale images, the process of Save, Reset, Open, and Histogram. Pre-processing to detect objects and cut images. Processing process to enhance image quality based on applied algorithms and postprocessing to test and calculate the error rate in the application.[28]

\section{Image Enhancement Process}

The process of enhancing CCTV image quality is carried out with 3 processes. The first process is the Pre-

CCTV images by taking screenshots of CCTV footage videos. The second process is the Processing process where this stage is the main stage of this application. [29]The last process is the Post-Processing stage, where this step is the result of the improvements carried out testing. The following is an explanation of each process of enhancing image quality:

1. Preprocessing Data

The data used in this process is CCTV footage video data sourced from Youtube web streaming videos (https://www.youtube.com/watch?v=73PvFu0B5TY\&has _verified=1). The picture below is an example of the preprocessing image:

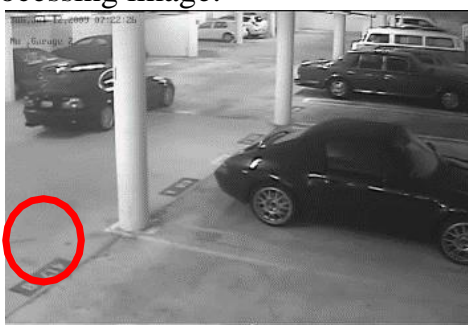

(a)

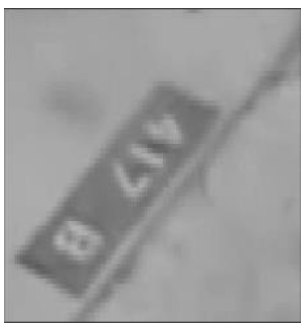

(b)

Figure 5. (a) Pre-Processing Result Image Step 1, (b) PreProcessing Result Image Step 2

2. Processing

The processing process is the stage to enhance the data that has been prepared in advance. This process is carried out on the application that has been made.

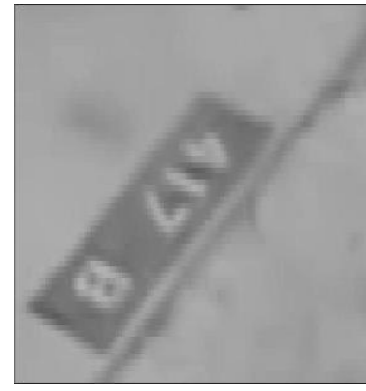

(a)

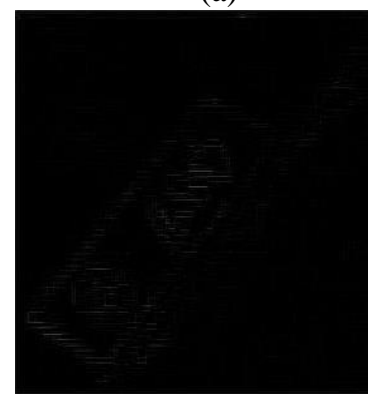

(c)

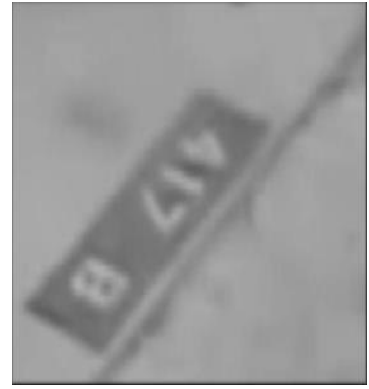

(b)

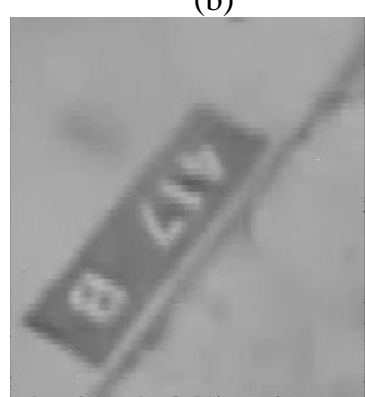

(d) 


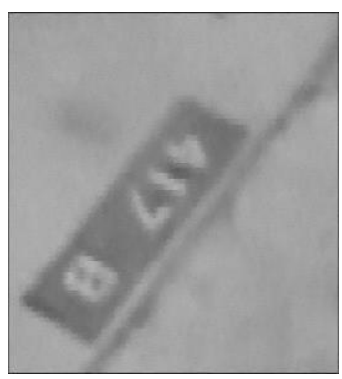

(e)

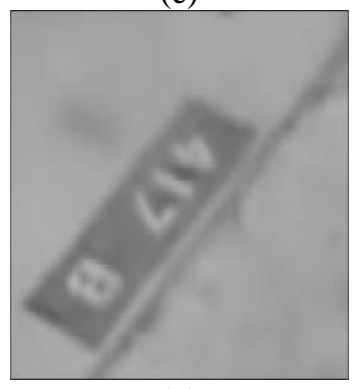

(g)

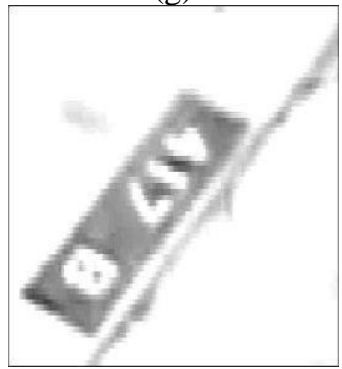

(i)

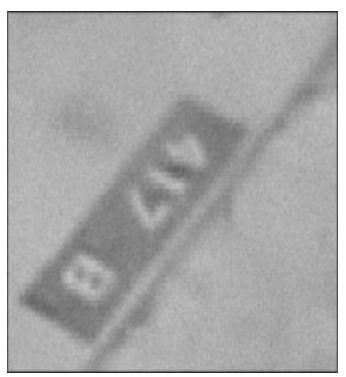

(f)

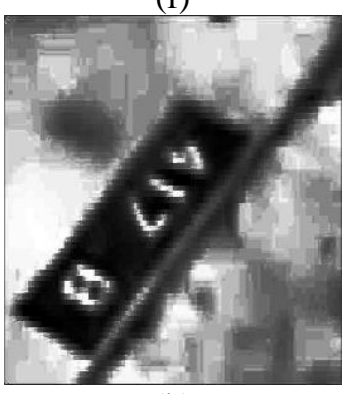

(h)

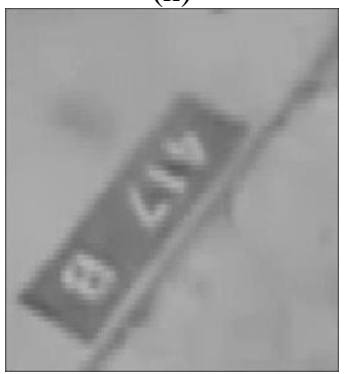

(j)
Figure 6. (a) Origin Image (b) LPF Result Image (c) HPF Result Image (d) MdF Result Image

(e) MeF Result Image (f) GF Result Image

(g) WF Result Image (h) Result Image HE

(i) CS Results Image (j) BI Results Image

\section{Post-processing}

The Post-Processing process is the process of testing algorithms for input images. Test parameters in the postprocessing process include MSE, PNSR, Run-Timing which are described in the following table:

Table 1. Results of MSE, PSNR and Timing-Run Test Values for Image Enhancement Algorithm

\begin{tabular}{cccc}
\hline $\begin{array}{c}\text { Parameter } \\
\text { Algorithm }\end{array}$ & MSE & PSNR & $\begin{array}{c}\text { Timing } \\
\text { Run }\end{array}$ \\
\hline Low Pass Filter & 190.85 & 107.6667 & $1.168911 \mathrm{~s}$ \\
High Pass Filter & 3663.26 & 1841.89 & $0.418909 \mathrm{~s}$ \\
Median Filter & 102.4766667 & 63.80666667 & $1.430568 \mathrm{~s}$ \\
Mean Filter & 28 & 30.59666667 & $47.761149 \mathrm{~s}$ \\
Gaussian Filter & 127.9933333 & 76.02 & $0.801191 \mathrm{~s}$ \\
Wiener Filter & 3719.213333 & 1872.293 & $0.423214 \mathrm{~s}$ \\
& & & \\
& & &
\end{tabular}

\begin{tabular}{cccc}
\hline Parameter & MSE & PSNR & $\begin{array}{c}\text { Timing } \\
\text { Run }\end{array}$ \\
\hline Histogram & 129.3033333 & 77.51333 & $0.386267 \mathrm{~s}$ \\
$\begin{array}{c}\text { Equalization } \\
\text { Contras Stretching }\end{array}$ & 507 & 263.1633 & 0.486704 \\
$\begin{array}{c}\text { Bicubic } \\
\text { Interpolation }\end{array}$ & - & - & 9.022161 \\
\hline
\end{tabular}

\section{Evaluation}

Overall, the results of this application are that the time needed to process the average timing run algorithm requires around 0.114627915 seconds, only the mean algorithm takes about 8-10 minutes to process. Visually the whole algorithm will not see the location of the repair, but by observing the histogram the image has a higher contrast or brightness and has a density around the mid-tone (gray) than the original image. The error value shown by MSE (Mean Square Error) produces an average value of 1058.512083 while the average value of PSNR is $541.61875 \mathrm{~dB}$ which indicates that image quality is relatively high.

On the other hand, the application to enhance the image quality that has been made still has disadvantages that need to be improved in order to produce a better image in terms of quality that can be seen visually. The shortcomings of the application for enhancement in image quality that has been made are as follows:

1. Collected algorithms cannot directly enhance quality that can be seen visually.

2. In some cases, the repaired image produces images with noise or blur.

3. The High Pass Filter algorithm cannot improve image quality but can visualize the edges of an image.

4. The Bicubic Interpolation algorithm only resizes the image, so that the visual image only looks like changing from RGB to Grayscale image. In assessment, this algorithm cannot be processed due to changes in the size of the image that has an effect on the image array.

5. The Object Detection method still cannot distinguish between human objects and objects other than humans. This method still requires a special algorithm for its development.

\section{CONCLUSION}

Based on the results of research that has been conducted on the application of enhancing the quality of forensic image applications, it has been successfully made to enhance image quality in which compile image enhancement algorithms. By making this application, the forensic image from CCTV can be improved or improved, so that visually and scientifically the image quality looks better.

Some image quality enhancement algorithms have been successfully applied in the application to improve the quality of images created. The algorithm that is applied is the image enhancement algorithm which consists of low 
pass filter, high pass filter, median filter, mean filter, Gaussian filter, Wiener filter, histogram equalization, contrast stretching and bicubic interpolation The algorithm has been successfully tested with Timing-Run, MSE and PNSR parameters. Based on histogram parameters it was found that the average overall algorithm provides enhancements to the resulting image with a higher contrast value than the original image and the resulting image has a density value in the mid-tone area which indicates that the enhanced image has better brightness and grayscale. original image. Based on the timing-run parameter, the average time required by the algorithm to enhance image quality for 0.114627915 seconds. The fastest processing time is a contrast stretching algorithm that only takes $0.386267 \mathrm{~s}$, while the longest processing time is the mean filter algorithm with a processing time of 47.761149s. Based on the MSE and PSNR parameters, the overall average MSE value was obtained at 1058.512083 and the overall average PSNR value was $541.61875 \mathrm{~dB}$, except the bicubic interpolation value that did not have MSE and PSNR values due to changes in the pixel array.

Some suggestions for further development is the need to increase the input value parameters of each algorithm, so that it will be known at what value the algorithm actually serves to enhance the quality of the image that can be seen visually. There needs to be further research on the application of enhancing the quality of forensic images on point operations, transformations and pseudo colors. It is also necessary to apply an edge repair algorithm to maximize the high pass filter algorithm function in the application. It is necessary to apply another linear interpolation algorithm that can enlarge image pixels and increase image size. Special algorithms are needed to maximize their functions such as convolution algorithms in deep learning or other algorithms that can detect objects more accurately.

\section{REFERENCES}

[1] Solihin, "Perbaikan Citra dengan Menggunakan Median Filter dan Metode Histogram Equalization.” [Online]. Available:

https://publikasiilmiah.ums.ac.id/handle/11617/4925.

[Accessed: 31-Jan-2020].

[2] N. M. Abdi and S. Aisyah, "Peningkatan Kualitas Citra Digital Menggunakan Metode Super Resolusi Pada Domain Spasial," Peningkatan Kualitas Citra Digit. Menggunakan Metod. Super Resolusi Pada Domain Spasial, vol. 9, no. 3, pp. 137-142, 2011.

[3] R. Adipranata and V. A. Sanjaya, "Pembuatan perangkat lunak untuk memperbaiki citra pada," pp. 266-273, 2006.

[4] H. Thendean and M. Sugiarto, "Penerapan Fuzzy IfThen Rules Untuk Peningkatan Kontras Pada Citra Hasil Mammografi," J. Inform., vol. 9, no. 1, pp. 1-7, 2009.

[5] M. N. Al-Azhar, Digital Forensik Panduan Praktis Investigasi Komputer. Salemba Infotek, 2012.

[6] P. Chyan et al., "Penerapan Image Enhancement Algorithm Untuk," vol. 12, pp. 278-281, 2017.

[7] C. Darujati, S. Anam, H. D. Cahyono, and A. B Gumelar, "Magnifikasi Perbaikan Citra Dijital Multi
Resolusi," J. Ilm. Mikrotek, vol. 1, no. 2, pp. 31-38, 2014.

[8] F. Nugroho, "Penggunaan inhibitor untuk meningkatkan ketahanan korosi pada baja karbon rendah," Angkasa, vol. 7, no. 1, pp. 151-158, 2015.

[9] R. A. Sholihin, "Implementasi Median Filter dan Metode Histogram Equalization Dalam Perbaikan Citra (Image Enhancement), 2014.

[10] M. F. E. M. Senan, S. N. H. S. Abdullah, W. M. Kharudin, and N. A. M. Saupi, "CCTV quality assessment for forensics facial recognition analysis," in Proceedings of the 7th International Conference Confluence 2017 on Cloud Computing, Data Science and Engineering, 2017, pp. 649-655.

[11] B. Hartono, "Analisa Teknik Adaptive Histogram Equalization dan Contrast Stretching untuk Perbaikan Kualitas Citra," J. Teknol. Inf. Din., vol. 19, no. 1, pp. 1$10,2014$.

[12] H. Nugroho, "Image Enhancement Pada Screen Capture CCTV Dengan Menggunakan Metode Histogram EKualisasi," Kinetik, vol. 2, no. 2, p. 99, 2017.

[13] A. Saikhu, N. Suciati, and S. Widhiantantri, "Perbaikan Citra Ber-Noise Menggunakan Switching Median Filter Dan Boundary Discriminative Noise Detection," vol. 2009, no. Snati, 2009.

[14] A. I. Restoration et al., "TeknikA 7," vol. 1, no. 32, pp. 7-13, 2009.

[15] D. Bansal, R. Bagoria, V. Sharma, and P. Student, "Digital Image Enhancement by Improving Contrast, Removal of Noise and Motion Blurring," Int. J. Innov. Res. Sci. Eng. Technol. (An ISO, vol. 3297, pp. 26012606, 2007.

[16] R. S. B. Sargun, "A Review of Medical Image Enhancement Techniques for Image Processing," Int. J. Curr. Eng. Technol., vol. 5, no. 2, pp. 1282-1286, 2015.

[17] Fricles Ariwisanto Sianturi, "Penerapan Metode Contrast Stretching Untuk Peningkatan Kualitas Citra Bidang Biomedis," J. Mantik Penusa, vol. 18, no. 2, pp. 70-75, 2015

[18] Sugiarti, "Peningkatan Kualitas Citra Dengan Metode Fuzzy," Ilk. J. Ilm., vol. 10, no. 1, pp. 100-104, 2018.

[19] A. Antonius, D. Triyanto, and I. Ruslianto, "Penerapan Pengolahan Citra dengan Metode Adaptive Motion Detection Algorithm pada Sistem Kamera Keamanan dengan Push Notification ke Smartphone Android," J. Coding Sist. Komput. Untan, vol. 3, no. 2, pp. 54-65, 2015.

[20] I. M. Dwi Putra Asana, I. M. Oka Widyantara, N. M. A. E. . Wirastuti, and I. B. P. Adnyana, "Metode Contrast Stretching untuk Perbaikan Kualitas Citra pada Proses Segmentasi Video," Maj. Ilm. Teknol. Elektro, vol. 16, no. 2, p. 1, 2017.

[21] S. Aripin and H. Sunandar, "Perancangan Aplikasi Perbaikan Citra Pada Hasil Screenshoot Menggunakan Metode Interpolasi Linier," Pelita Inform. Budi Darma, vol. XV, no. June, pp. 51-58, 2017.

[22] H. R. Fajrin, "Perbandingan Metode Untuk Perbaikan Kualitas Citra Mammogram," Simetris J. Tek. Mesin, Elektro dan Ilmu Komput., vol. 7, no. 2, p. 657, 2016.

[23] K. Kapoor and S. Arora, "Colour Image Enhancement based on Histogram Equalization," Electr. Comput. Eng. An Int. J., vol. 4, no. 3, pp. 73-82, 2015.

[24] M. Kusban, "Menggunakan Proses Ridge Regression," pp. 42-49, 2013

[25] A. H. Nasyuha, P. Studi, S. Informasi, T. D. Medan, and 
P. Citra, "Implementasi Pengolahan Citra Dengan Menggunakan Teknik Konvolusi Untuk Pelembutan

Citra ( Image Smoothing ) Dalam,” pp. 150-162, 2012.

[26] P. Yulianto, "Peningkatan Citra Untuk Memperjelas Foto Brain CT Scan,” J. Ilm. Semesta Tek., vol. 86 11, no. 1, pp. 86-95, 2008.

[27] F. Sianturi, "PENERAPAN METODE CONTRAST STRETCHING UNTUK PENINGKATAN KUALITAS CITRA BIDANG BIOMEDIS.”.

[28] F. A. Hermawati, Pengolahan Citra Digital. Jakarta: Penerbit Asri, 2013.

[29] N. Heryana and R. Mayasari, "Implementasi Nose Removal Menggunakan Wiener Filter untuk Perbaikan Citra Digital," Syntax J. Inform., vol. 5, no. 2, pp. 159 164, 2016. 